\title{
Effectiveness of the Use of AFO Rigid in Cases of Postoperative Diabetes Mellitus Charcot Joint
}

\author{
Nur Rachmat* and Zenitha Bela Pratiwi Kusumawati \\ Prosthetic Orthotic Course Politeknik Kesehatan Kemenkes Surakarta \\ E - mail : nurrachmat@gmail.com*
}

\begin{abstract}
Charcot feet are a condition that affects the bones, joints, and soft tissues of the feet and ankles, where the initial phase is characterized by inflammation. Charcot states that joint damage is related to central nervous system damage that controls joint and bone nutrition. Repeated trauma to the denervation joint is a factor that accelerates the onset of CN. Method: This study uses qualitative research, and the results of this study are descriptive. Results of the analysis: the results of interviews with patients. The patient cannot stand to rest on the foot. The purpose of the orthosis is for fixation. Conclusion: before using a rigid AFO the patient performs his activities by way of peeling to the floor. With the use of rigid AFO this can help patients in their daily activities more independently, so as to improve the quality of life of patients.
\end{abstract}

Keywords: Charcot joint, Diabetes Melitus, postoperative DM.

\section{INTRODUCTION}

Diabetic foot is infection, ulceration, and/or damage to deep connective tissue associated with neuropathy and peripheral vascular disease of the lower limbs, ulcers, neuropathy and gangrene. (Subekti, 2006)

The prevalence of diabetes mellitus (DM) is increasing worldwide. Indonesia now ranks fourth in terms of the highest number of diabetics after the United States, China and India. The World Health Organization (WHO) estimates that the number of people with DM in Indonesia will increase from 8.4 million in 2000 to around 21.3 million in 2030.

The greatest increase is type 2 diabetes, especially in young and obese patients. With increasing life expectancy, the prevalence of diabetes complications also increases as quoted in the 2016 Wulansari journal.

Charcot's foot is a condition that it affects the bones, joints, and soft tissues of the feet and ankles, where the initial phase is characterized by inflammation. Charcot's foot is a progressive condition characterized by joint dislocations, pathological fractures, and severe architectural damage to the foot that can worsen the deformity in the journal Wulansari, 2016.

The French theory put forward by JeanMartin in the journal Wulansari 2016 Charcot states that joint damage is related to damage to the central nervous system which controls the nutrition of joints and bones. The German theory by Volkman and Virchow states that repetitive trauma to denervated joints is a precipitating factor in the development of $\mathrm{CN}$.

Prosthetic orthotics is part of teamwork in the field of teamwork in the field of medical rehabilitation. An orthosis and prosthesis specialist must be able to work closely with orthopedic surgeons, medical rehabilitation doctors, orthopedic nurses, physiotherapists, occupational therapists, psychologists, psychiatrists, and social workers. Orthotics and prosthetics are two different things, but they are related. Orthotics is an engineering science in a different, but related medical field. (Arjuna, 2015).

Based on the case to be studied, the researcher chose an orthosis in the form of Ankle 
Foot Orthosis with rigid type, with the aim of fixation. And the patient underwent bone graft surgery, in which $1 / 3$ of the fibula was excised. So the purpose of the orthosis is so that the orthosis can improve the patient's foot that has been operated on.

\section{METHODS}

This study uses a qualitative approach by using in-depth interviews, where researchers can explore data more broadly and lead to certain problems in more detail. The case study population in this study were patients with diabetes mellitus after Charcot joint surgery.

The qualitative assessment process involves important efforts, such as asking questions and procedures, collecting specific data from participants, analyzing specific data from participants, analyzing data inductively from certain themes to certain themes. common sense, and interpret the meaning of data.

This study does not prioritize the size of the population or sampling, even the population or sampling is very limited. If the data collected is indepth and can explain the phenomenon under study, there is no need to look for another sampling. Here, the emphasis is on the depth (quality) of the data, not the amount (quantity) of the data.

\section{RESULTS AND DISCUSSION}

The findings of this study will be presented and discussed based on theories related to marketing communication strategies.

The results of this study were strengthened by in-depth interviews from respondents who submitted the following statements: "Initially I didn't know why my feet were getting big over time, after a while I couldn't stand up because I felt pain in my feet. My daily life is just sliding on the floor and using a wheelchair. And what I felt after my foot surgery was like there was cement in it."

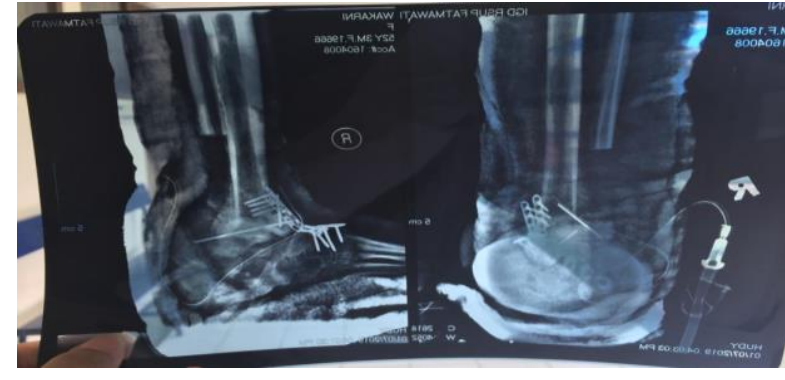

Figure 1. X-ray of the patient's right leg affected by the Charcot joint

Diabetes mellitus can negatively impact several organ systems including joints and tendons. This usually occurs in the Achilles tendon where Advanced Glycosylate Ended Products (AGEs) bind to collagen molecules in the tendon causing loss of elasticity and even shortening of the tendon. Due to the inability to dorsiflex the soles of the feet, in other words, the metatarsal arches and the head experience high and prolonged pressure due to gait disturbances. (Rina et al, 2016)

The destructive changes that occur in Charcot's foot cause damage to the medial longitudinal arch, which results in a biomechanical gait. Changes in calcane pitch cause strain on the ligaments of the metatarsal, cuneiform, navicular and other small bones that increase the length of the arch in the foot. These degenerative changes will later change the way you walk (gait), resulting in abnormal loadbearing stresses that cause the leg to collapse. Ulceration, infection, gangrene, and loss of limbs are common outcomes if the process is not stopped at an early stage. (Rina et al, 2016)

Charcot's foot is a progressive condition characterized by joint dislocations, pathological fractures, and severe architectural damage to the foot that can exacerbate the deformity in the journal Wulansari, 2016. 

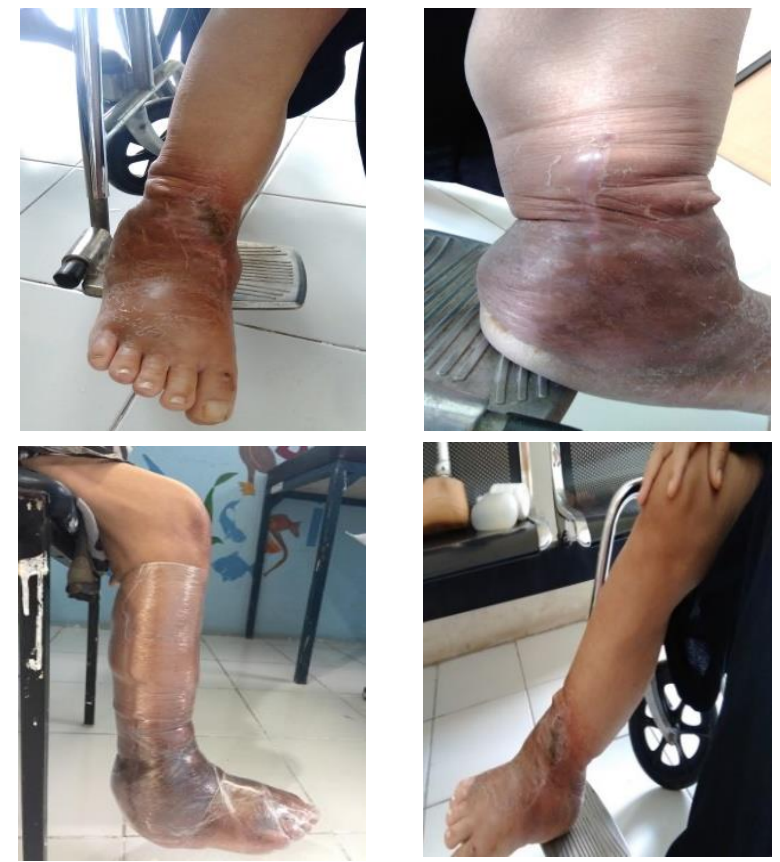

Figure 2. Condition of the patient's feet after surgery

When the patient performs the exercise process using an orthosis device in the form of an Ankle Foot Orthosis with the Rigid type, the patient is not allowed to stand because the function of the device is only for fixation and the patient has just undergone surgery. So the patient is only allowed to sit in a wheelchair using a rigid type of Ankle Foot Orthosis.
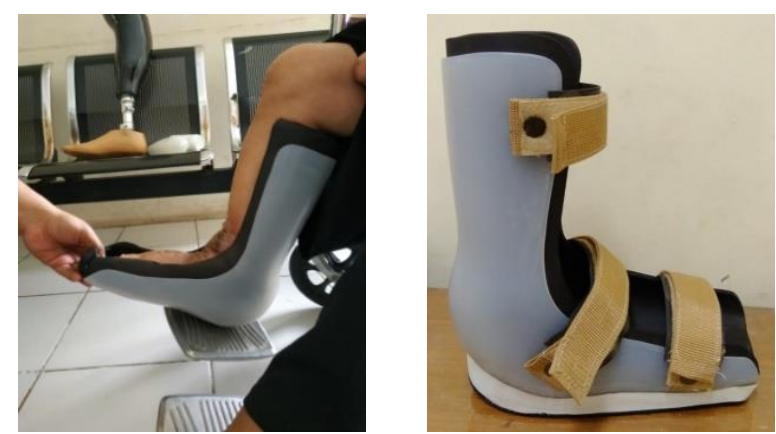

\section{Figure 3. use of rigid AFO}

Analysis of Observation Results using a rigid foot orthosis. From the results of interviews with patients. The patient is unable to stand. The purpose of the orthosis is for fixation.

\section{CONCLUSIONS}

Based on the results of interviews conducted with Charcot joint patients, where before using the rigid AFO the patient carried out his activities by sliding to the floor.

With the use of this rigid AFO, it can help patients in daily activities to be more independent, so that they can improve the patient's quality of life later.

Suggestion: The suggestion that the author can give is that Charcot joint patients be given education about orthosis hygiene care and pay more attention to patients

\section{REFERENCES}

Almatsier, Sunita. 2009. Prinsip Dasar Ilmu Gizi. Gramedia Pustaka Utama, Jakarta

American Diabetes Association. 2010. Cinical Practise Recom-mendations Report of The Expert Committee on the Diahnosis Classification of Diabetes Melitus Care. USA.

Arjuna Medical Orthopedic. (2015). Ortotik Prostetik.

Anandi. (2004). Bacteriologiy of Diabetic Foot Lesion. Indian Journal of Medical Microbiology.pp.175-178.

Comi J, Bulechek GM. (2006). Nursing Intervention Classification (NIC). St Louis: Mosby Years Book.

Darmono. (2007). Pola Hidup Sehat Penderita Diabetes Mellitus. Badan Penerbit Universitas Diponegoro, pp.15-30, Semarang.

Max E, Otiniano. (2012). Factors Associated With Poor Glycemic Control In Older Mexican American Diabetic Aged 75 Years And Older. Jurnal of Diabetes and Its Complications.

Merza Z, Tesfaye. (2003). The Risk Factorsfor Diabetic Foot Ulceration. pp.125-129.

Singh N, Armstrong DG, Lipsky BA. (2005). Preventing Foot Ulcers in Patient with Diabetes. American Medical Association JAMA. January 12, 2005-Vol 293 No.2:293. pp,217-228.

Soegondo, Subekti. (2007). Penatalaksaanaan DM Terpadu. Jakarta: EGC. 
Journal of Local Therapy

Vol. 1, No. 1, February 2022

p-ISSN: 2809-3240; e-ISSN: 2810-0875

pp: 14 - 17

Pujiningsih. (2012). Pengaruh Pendidikan Kesehatan tentang Perawatan Kaki Diabetik Non Ulkus terhadap Kemampuan Diabetis dalam Melakukan Perawatan Kaki di Wilayah Kerja Puskesmas Kedungwuni II Kab. Pekalongan. Jurnal Media Komunikasi Ilmu Kesehatan Vol 2.
JOURNAL OF LOCAL THERAPY

Wulansari, Suci (2016). Penanganan Kaki Charcot Diabetik. Pusat Humaniora Kebijakan Kesehatan dan Pemberdayaan Masyarakat Surabaya Indonesia.

Zahra Y. (2011). Clinical and Behavioral Factors Associated With Management Outcome In Hospitalized Patients With Diabetic Foot Ulcer. 